Svitlana Shymon,

Dr. Sc., Associate Professor, Kyiv National Economics University named after Vadym Hetman, Ukraine

Evhenia Kolomiets-Ludwig,

Ph. D., Associate Professor, Kyiv National Economics University named after Vadym Hetman, Ukraine

Joanna Osiejewicz,

Dr. Hab., University of Warsaw, Poland

Dariusz Krawczyk,

Ph.D., Municipal Office in Zabre, Poland

Bozena Kaminska,

Ph.D., The London Academy of Science and Business, United Kingdom

\title{
THE ROLE OF COUNTRY BRAND IN PROVIDING ECONOMIC RESILIENCE
}

Abstract. The paper summarised arguments and counterarguments on analysis of economic resilience. The bibliometric analysis on economic resilience using the software VOSviewer allowed identifying the four core scientific schools: R. Martin (University of Cambridge, Cambridge, United Kingdom); A. Rose University of Southern California, Los Angeles, United States; C.S. Holling; H. Wolman (The George Washington University, Washington, D.C., United States); I. Briguglio (L-Universita ta'Malta, Msida, Malta). The generalisation of the scientific papers and approaches on solving issues mentioned above proved that the core indicators of economic resilience assessment were macroeconomic stability; microeconomic market efficiency; good governance; social development. The paper aimed at the analysis of the marketing determinants impact on the economic vulnerability of the country. The hypothesis of the paper was no statistically significant difference in the level of economic vulnerability for countries that implement effective branding policies and do not take appropriate actions. The study checked hypothesis using the methods and instruments as follows: for the normal distribution of the statistical data - the Shapiro-Wilk test; verification of the equality of dispersion in the statistical data using the Levine's test; parametric (One-way ANOVA: F-test) or nonparametric test (Kruskal-Wallis rank test). The object of the investigation was European Union countries which were classified on the six groups by the experts of the FutureBrand rating. The empirical data confirmed the hypothesis mentioned above. Thus, the findings proved no statistically significant difference between the leading indicators of the level of economic vulnerability according to the essential component - macroeconomic stability, which was estimated using indicators: General government deficit (-) and surplus (+) - annual data; unemployment rate.

Keywords: brand, government deficit, government surplus, unemployment rate, ANOVA.

Introduction. Economic resilience means stable economic functioning and developing. At the same time, the providing of economic resilience depends on the effect of the deferent parameters in time and place. What parameters could be classified as follows: internal and external. The globalization and integration process, the attractiveness of the investors provoke the growing of recourses inequality and as a consequence in providing of the Economic resilience (Rekunenko et al.,2019; Boiko et al., 2019). The most significant impact on macroeconomic had the internal factors as follows: Level of the economic development and dynamic; economic and fiscal balance; inequality of the income and assets; corruption and features of the social and economic policies (Vasylieva et al., 2017; Bilan et al.,2019a; Bilan et al.,2019b; Ibragimov, 2019). At the same time, strengthening of the competitiveness at the resource market provokes to have the own non-repeatable image by each country (Shvindina, 2019). In this case, one of the key goals was to develop a positive international image by the country. It leads to increasing life quality and strengthening the relationship in the global market.

Literature Review. In Scopus, the first papers which focused on the investigations of the «economic resilience» were published Van De Klundert (1986) and Herring (1986). Herring (1986) analysed economic resilience as the requirements of the Cultural differences among the Kickapoo Indians of the Southwest. Van De Klundet (1986) proposed to estimate of economic resilience for two-country analysis using the modified Cobb-Douglas functioning. From the beginning of 1986 years, the numbers of papers on

Cite as: Shymon, S., Kolomiets-Ludwig, E., Osiejewicz, Jo., Krawczyk, D. \& Kaminska, B. (2020). The Role of Country Brand in Providing Economic Resilience. Marketing and Management of Innovations, 1, 303-312. http://doi.org/10.21272/mmi.2020.1-26 

Economic Resilience

economic resilience had being increased (Figure 1). Thus, in 1986 the scientists published only two papers in Scopus, in the 2018 year - 77, 2019 year - 72. For 1986-2019 years the average growth of publications was $110 \%$, and the average rate of increment $-10 \%$.

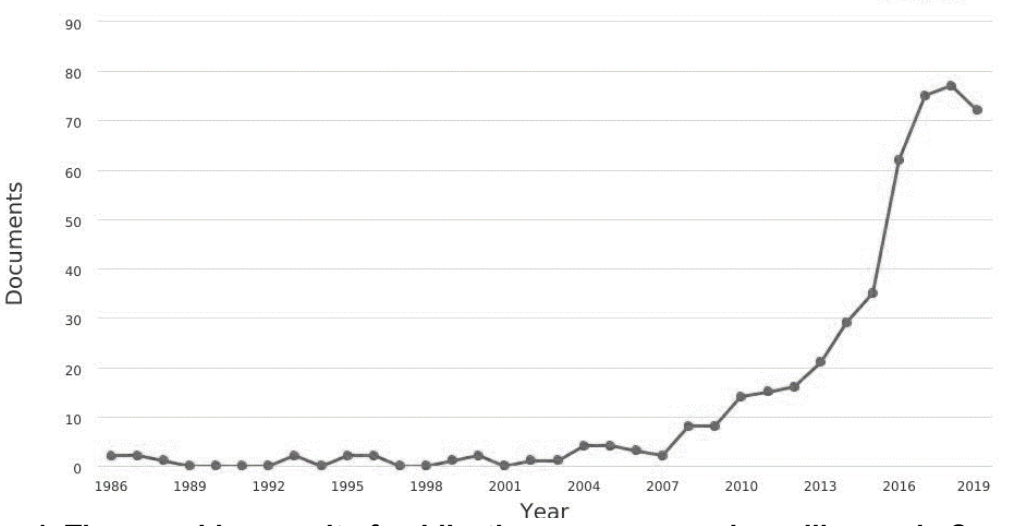

Figure 1. The searching result of publications on «economic resilience» in Scopus Source: developed by the authors.

The scientific paper (Simmie \& Martin, 2010) was the most cited paper in Scopus (556 citations), Google Scholar (1177 citations). That paper based on the theoretical background which focused on the regional economic stability. The authors highlighted the necessity of transformation from stable to regional development concept. It was justified by the fact «the firms, organisations and institutions that comprise regional economies are continually changing and adapting to their economic environments. These changes are increasingly driven by the creation, acquisition and commercial exploitation of new knowledge. These processes are never in equilibrium» (Simmie \& Martin, 2010).

The paper Martin (2012) dealt with the analysis of regional economic resilience and occupied second place on the citation score in Scopus (536 citations). In the paper, the author paid attention to the necessity of implementing the regional economic stable development considering the changes and vulnerable external conditions. The author suggested that the primary dimension of regional economic resilience assessment were: resistance, recovery, renewal and re-orientation (realignment or adaptation) (Martin, 2012). It should highlight, that the authors underlined the necessity of merging two concepts under the understanding the definitions of «regional economic resilience»: stability and hysteresis. In this case, the hysteresis concept allowed estimating of the shocks' impact on economic development.

Rose and Liao (2005) in the empirical investigation, estimated the stability of regional development and the impact of earthquakes and other disasters using the principle of general equilibrium modelling. In this case, the author used the general principals of the main postulates of the production theory. This paper gad 369 citations in Scopus.

The analysis of the papers in Scopus showed that the considerable background on the theme mentioned above had the authors as follows (1986-2019): и Adam Z. Rose (University of Southern California, Los Angeles, United States ) - 16, Gillian Bristow (Cardiff University, Cardiff, United Kingdom) - 8, Adrian Healy (Cardiff University, Cardiff, United Kingdom) - 8, Gian Paolo Cimellaro (Politecnico di Torino, Turin, Italy) - 5 (Figure 2). That findings correlate with the highest numbers of published papers with the authors' affiliations: University of Southern California - 14, Cardiff University - 12, The Ohio State University - 10, University of Cambridge - 10. 


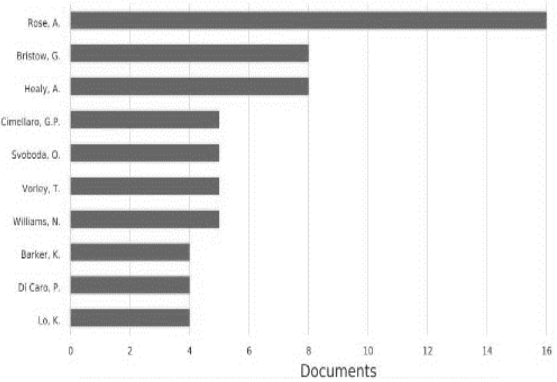

a)

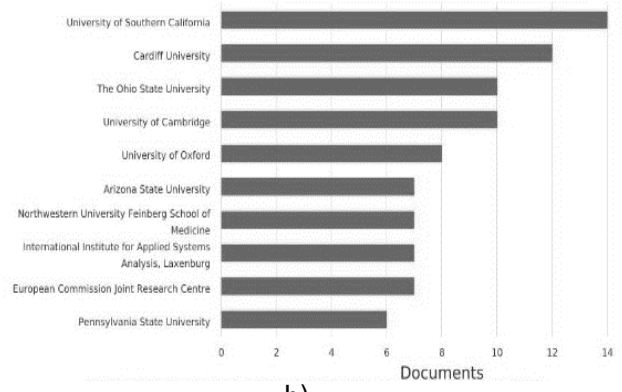

b)

Figure 2. The searching findings of publications on «economic resilience» by author and affiliation in Scopus

Source: developed by the authors

The findings allowed identifying the four clusters of scientific schools with the robust input in the investigation on economic resilience (Figure 3): 1) R. Martin (the University of Cambridge, Cambridge, United Kingdom); 2) A. Rose University of Southern California, Los Angeles, United States; 3) C.S. Holling; 4) H. Wolman (The George Washington University, Washington, D.C., United States); 5) I. Briguglio (LUniversità ta' Malta, Msida, Malta).

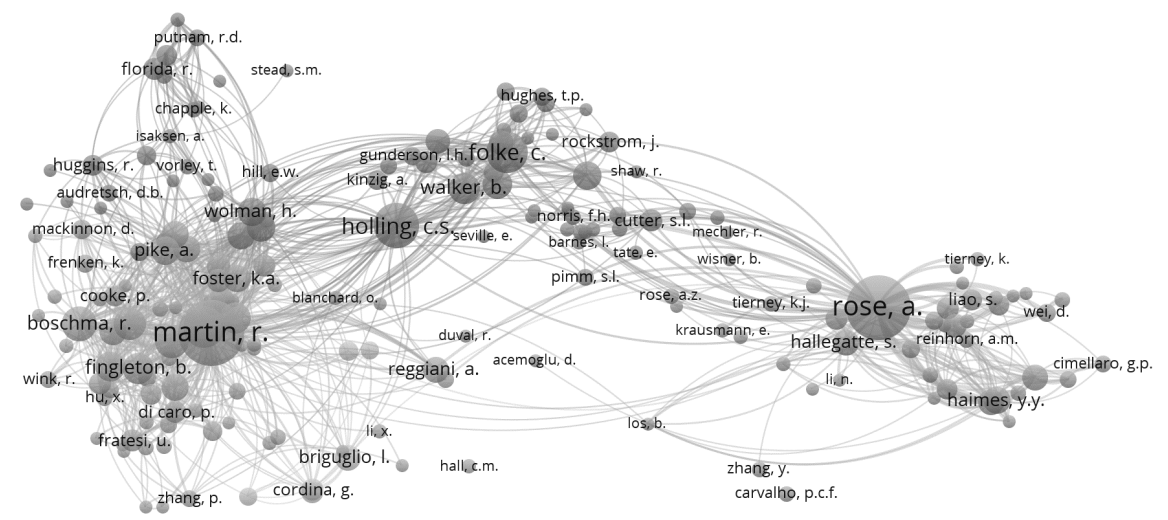

Figure 3. The co-citation analysis with using software VOSviewer

Source: developed by the authors

In the paper, I. Briguglio y «economic resilience» analysed at the country level. Thus, in the papers (Briguglio et al., 2006; Briguglio et al., 2008; Briguglio et al., 2009; Briguglio, 2016) the authors defined economic vulnerability as «the exposure of an economy to exogenous shocks, arising out of economic openness» тоді, як «еconomic resilience» - «the policy-induced ability of an economy to withstand or recover from the effects of such shocks». In this case, the scientist used to estimate the economic resilience the following indicators: the fiscal deficit to GDP ratio, unemployment rate, inflation rate, the external debt to GDP ratio (value of macroeconomic stability); Economic Freedom of the World Index (explain to indicators Microeconomic market efficiency and Good governance); Human Development Index (allowed estimating Social development) (Briguglio et al., 2006; Briguglio et al., 2008; Briguglio et al., 2009; Briguglio, 2016). At the same time, in the papers (Dinnie et al.,2010; Florek, 2005; Supphellen 
\& Nygaardsvik, 2002; Diamantopoulos et al., 2011; Bivolaru et al., 2009; Supphellen \& Nygaardsvik, 2002) the scientists confirmed that brand and image become the essential marketing determinants which allowed increasing of tourists, investment attractiveness, quality of life, competitiveness at the global market. In the paper (Bilan et al., 2019), the authors used Generalized Least Squares (GLS) model (formula 1) to confirm the statistical significance impact of country brand on macroeconomic stability.

$$
M S=\alpha+\beta_{1} M C B I+\beta_{2} P D I+\beta_{3} I D V+\beta_{4} M A S+\beta_{5} U A I+\beta_{6} L T O
$$

where $M S$ - macroeconomic stability; MCBI - the value of the brand; DI, IDV, MAS, UAI, LTO social-value determinants of country's brand; $\beta_{1} \ldots \beta_{6}$ - parameters of the model which should be estimated.

The paper aimed to analyse the marketing determinants on the economic vulnerability of the country.

Methodology and research methods. The core hypothesis of the paper was:

$\mathrm{HO}$ : it is no statistically significant difference in the level of economic vulnerability for countries that implement effective branding policies and do not take appropriate action;

$\mathrm{H} 1$ : it is a statistically significant difference in the level of economic vulnerability for countries that implement effective branding policies and do not take appropriate action.

At the first stage, the authors did the tests on normal distributions of the data using the test of ShapiroWilk (Razali \& Wah, 2011):

$$
W=\frac{\left(\sum_{i=1}^{n} a_{i} x_{(i)}\right)^{2}}{\sum_{i=1}^{n}\left(x_{i}-\bar{x}\right)^{2}}
$$

where $x_{(i)}$ - the smallest number in the sample; $\bar{x}$ - the sample mean. 2009):

At the next stage, the equality of the dispersion in the raw data using Levine's test (Gastwirth et al.,

$$
W=\frac{(N-k)}{(k-1)} \frac{\sum_{i=1}^{k} N_{i}\left(Z_{i}-Z_{. .}\right)^{2}}{\sum_{i=1}^{k} \sum_{j=1}^{N_{i}}\left(Z_{i j}-Z_{i .}\right)^{2}}
$$

where $\mathrm{Z}$ - the mean of the group; $\mathrm{k}$ - the number of different groups to which the sampled cases belong; $N_{i}$ - the number of cases in the i-th group

In the end, considering the findings from the previous stage (figure 4), the authors used parametric (One-way ANOVA: F-test) or non-parametric (Kruskal-Wallis rank test) tests (Butt, 2006).

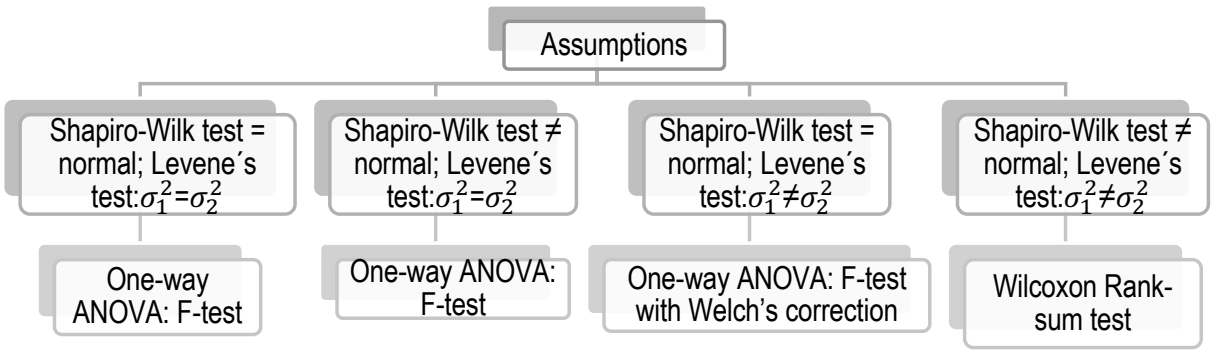

Figure 4. The conceptual framework of the investigation 

Economic Resilience

Source: developed by the authors.

The object of the investigation was European Union countries. The authors used the data from company FutureBrand (2019) to estimate the efficiency of country brand promotion. The experts from FutureBrand proved that the Country Brand Index (CBI) allowed estimating the country's place compare with the other country and identify the bottleneck of the country's policy. It allowed developing the corresponding strategy to overcome the issues.

The results of the analysis showed that according to FutureBrand (2019) all countries were classified by six groups: the first group - the countries which occupied the 1-10 places (Austria, Denmark, Finland, Germany, Luxembourg, Sweden); 2 group - countries on 11-20 places (France, Italy, Netherlands); 3 group - countries on 21-30 (Belgium, Portugal, Spain); 4 group - countries on 21-30 (Czech Republic, Greece, Hungary, Ireland, Slovakia); 5 group - countries on 41-50 (Romania, Poland); 4 group - countries were not included in the rating (Bulgaria, Croatia, Cyprus, Estonia, Latvia, Lithuania, Malta, Slovenia).

Results. According to (Briguglio et al., 2006; Briguglio et al., 2008; Briguglio et al., 2009; Briguglio, 2016) as the main reassurance of economic vulnerability was an indicator of the macroeconomic stability using the parameters: General government deficit (-) and surplus (+) - annual data; unemployment rate. Figure 5 showed the descriptive statistics of the selected variables.

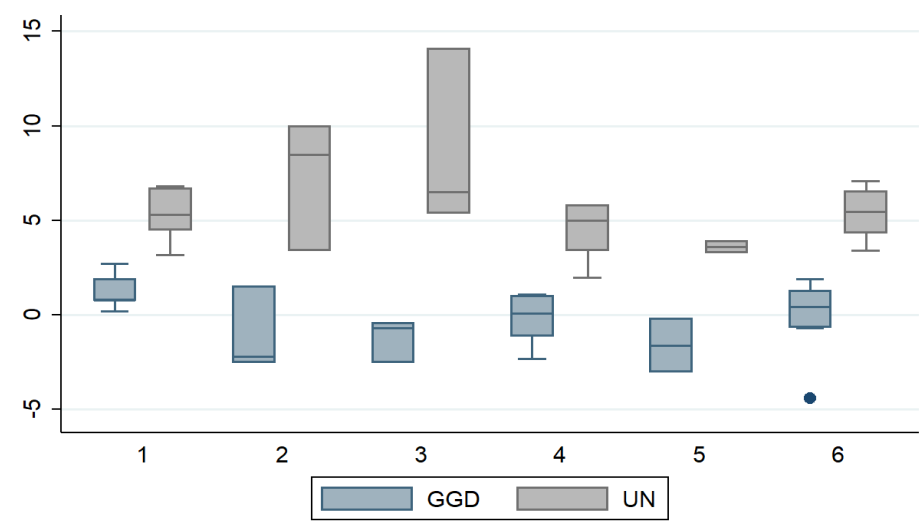

Figure 5. The average values of the variables of economic vulnerability based on the macroeconomic stability

Source: developed by the authors

Table 1 contained the findings of Shapiro-Wilk on normal distribution for indicators GGD and UN.

Table 1. Shapiro-Wilk W test for standard data

\begin{tabular}{rccccc}
\hline Variable | & Obs & W & V & z & Prob>z \\
GG I & 27 & 0.79542 & 6.014 & 3.685 & 0.00011 \\
GGD I & 26 & 0.95850 & 1.187 & 0.351 & 0.36288 \\
\hline
\end{tabular}

Source: developed by the authors.

Considering the findings in Table 1, the $p$-values under (Prob>z) only for indicators UN was smaller than 0.05 , which indicates that the normality assumption was violated. At the same time, for GGD the $p$ values under (Prob>z) more than 0.05 , which did not allow rejecting the hypothesis on the normal distribution for selected data. Tables 2 and 3 involved the findings of Levine's test on checking the dispersion of UN and UN. 
S. Shymon, E. Kolomiets-Ludwig, Jo. Osiejewicz, D. Krawczyk, B. Kaminska. The Role of Country Brand in Providing Economic Resilience

Table 2. The findings of Levine's test on the equality of variances UN

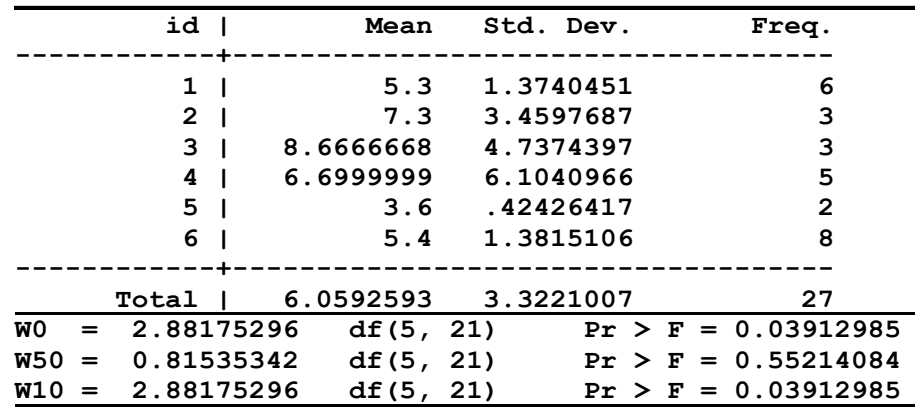

Source: developed by the authors.

For these data (table 2), the results cannot reject the null hypothesis that the variances UN are equal.

Table 3. The findings of Levine's test on the equality of variances GGD

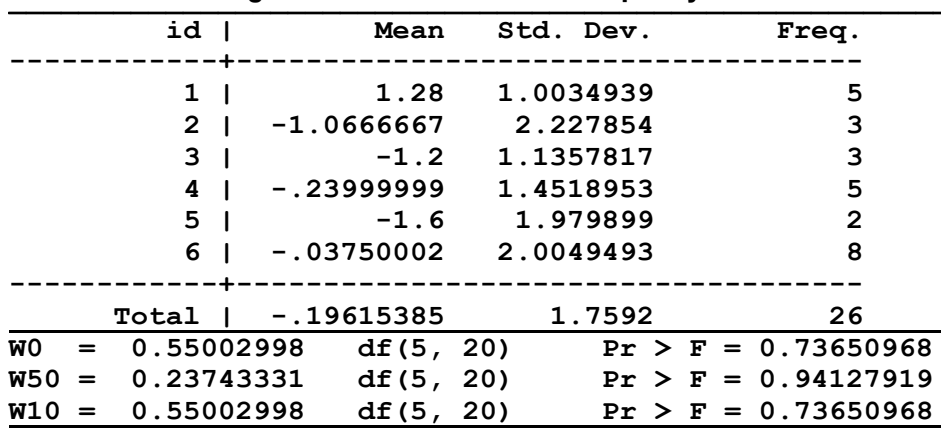

Source: developed by the authors.

The p-values of W0, W50, and W10 for GGD are higher than 0.05 and, thus, not significant. It means that there is no reason to think that the variances for all group counties are different. The obtained results Shapiro-Wilk and Levene's tests confirmed the using of Kruskal-Wallis rank test for UN and GGD - Oneway ANOVA: F-test. The results Kruskal-Wallis rank test and One-way ANOVA: F-test showed in Tables 4 and 5 .

Table 4. The findings of the Kruskal-Wallis rank test for UN

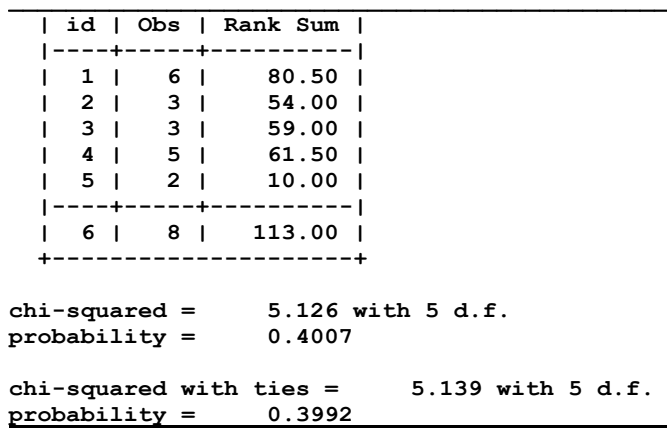


S. Shymon, E. Kolomiets-Ludwig, Jo. Osiejewicz, D. Krawczyk, B. Kaminska. The Role of Country Brand in Providing Economic Resilience

Source: developed by the authors.

Kruskal-Wallis rank test did not confirm the statistically significant differences between six countries group on indicators UN, $x 2(2)=5,139, p=0,3992$.

Table 5. The findings of One-way ANOVA: F-test for GGD

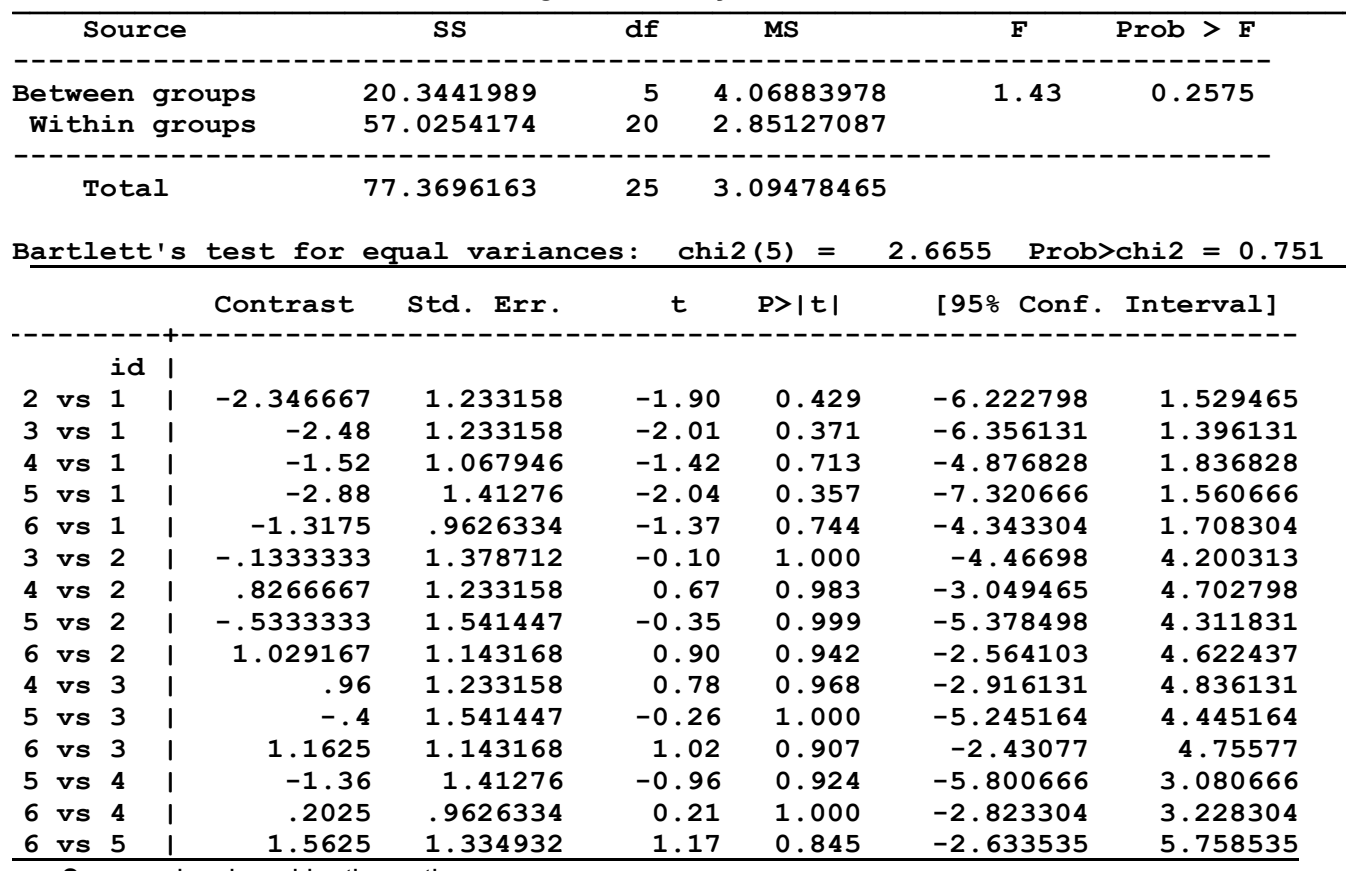

Source: developed by the authors.

The results of Table 5 indicated that there was no statistically significant difference between the groups defined by one-way ANOVA $(F(2,57)=1,43, p=0,2575)$. Tukey's post-test showed that the GGD level had no statistically significant difference between groups.

Conclusions. The findings did not confirm the statistical significance differences between core indicators of economic vulnerability relevant the macroeconomic stability. The study estimated macroeconomic stability by the indicators as follows: General government deficit (-) and surplus (+) annual data; unemployment rate. Noted, that for the further investigations it is necessary to analyse of the all components of economic vulnerability: macroeconomic stability; microeconomic market efficiency; good governance; social development (Briguglio et al., 2006; Briguglio et al., 2008; Briguglio et al., 2009; Briguglio, 2016). Besides, the core limitation of the investigation was using the production theory on brand assessments. In this case, it is necessary to estimate base on the consumers and fiscal approaches. The consumers' approach based on a personal study of the target audience perception of the country, while the using a fiscal approach allowed avoiding that limitation and used objective secondary data to assess the impact of the country's brand on economic vulnerability.

Author Contributions: conceptualisation, S.S. and Jo. O.; methodology, E. K-L. and D. K.; validation, B. R., S. S. and Jo. O.; formal analysis, E. K-L.; investigation, S. S.; resources, D. K.; data curation, D. K. and S. S.; writing-original draft preparation, D. K., S. S.; writing-review and editing, Jo. O., D. K. and E. K-L.; visualisation, S. S. and B. K.; supervision, B. K.; project administration, E. K-L.; performed the analysis and visualisation of results, E. K-L. and S. S. 


\section{References}

Bilan, Y., Brychko, M. M., Buriak, A. V., \& Vasylieva, T. A. (2019). Financial, business and trust cycles: the issues of synchronization. [Google Scholar] [CrossRef]

Bilan, Y., Lyeonov, S., Lyulyov, O., \& Pimonenko, T. (2019). Brand management and macroeconomic stability of the country, [Zarządzanie marką i stabilność makroekonomiczna kraju]Polish Journal of Management Studies, 19(2), 61-74. doi:10.17512/pjms.2019.19.2.05 [Google Scholar] [CrossRef]

Bilan, Y., Rubanov, P., Vasylieva, T., \& Lyeonov, S. (2019). The influence of industry 4.0 on financial services: Determinants of alternative finance development. Polish Journal of Management Studies, 19. [Google Scholar] [CrossRef]

Bivolaru, E., Andrei, R., \& Purcaroiu, G. V. (2009). Branding Romania: a pestel framework based on a comparative analysis of two country brand indexes. Management \& Marketing, 4(4). [Google Scholar]

Boiko A., Bilan Y., Kuzmenko O. Research on the Impact of Industry 4.0 on Entrepreneurship in Various Countries Worldwide. 33rd IBIMA Conference (Web of Science ta Scopus), 10-11 April 2019. Granada, 2019. [Google Scholar]

Briguglio, L. P. (2016). Exposure to external shocks and economic resilience of countries: Evidence from global indicators. Journal of Economic Studies, 43(6), 1057-1078. doi:10.1108/JES-12-2014-0203 [Google Scholar] [CrossRef]

Briguglio, L., Cordina, G., Farrugia, N., \& Vella, S. (2006). Conceptualizing and measuring economic resilience. Building the Economic Resilience of Small States, Malta: Islands and Small States Institute of the University of Malta and London: Commonwealth Secretariat, 265-288. [Google Scholar]

Briguglio, L., Cordina, G., Farrugia, N., \& Vella, S. (2008). Economic vulnerability and resilience. United Nations research paper, 55. [Google Scholar]

Briguglio, L., Cordina, G., Farrugia, N., \& Vella, S. (2009). Economic vulnerability and resilience: concepts and measurements. Oxford development studies, 37(3), 229-247. [Google Scholar] [CrossRef]

Butt, N. S. (2006). ANOVA with Summary Statistics: A Stata Macro. Pak. j. stat. oper. res, 2(1), 57-62. [Google Scholar] [CrossRef]

Diamantopoulos, A., Schlegelmilch, B., \& Palihawadana, D. (2011). The relationship between country-of-origin image and brand image as drivers of purchase intentions. International Marketing Review. [Google Scholar] [CrossRef]

Dinnie, K., Melewar, T. C., \& Fetscherin, M. (2010). The determinants and measurement of a country brand: the country brand strength index. International Marketing Review. [Google Scholar]

Florek, M. (2005). The country brand as a new challenge for Poland. Place Branding, 1(2), 205-214. [Google Scholar] [CrossRef]

FutureBrand. (2019). Country brand index. Retrieved from : https://www.futurebrand.com/futurebrand-country-index

Gastwirth, J. L., Gel, Y. R., \& Miao, W. (2009). The impact of Levene's test of equality of variances on statistical theory and practice. Statistical Science, 343-360. [Google Scholar]

Herring, J. B. (1986). Cultural and economic resilience among the Kickapoo Indians of the Southwest. Great Plains Quarterly, 263275. [Google Scholar] [CrossRef]

Ibragimov, Z., Vasylieva, T., \& Lyulyov, O. (2019). The national economy competitiveness: effect of macroeconomic stability, renewable energy on economic growth. Economic and Social Development: Book of Proceedings, 877-886. [Google Scholar]

Martin, R. (2012). Regional economic resilience, hysteresis and recessionary shocks. Journal of economic geography, 12(1), 1-32. [Google Scholar] [CrossRef]

Razali, N. M., \& Wah, Y. B. (2011). Power comparisons of shapiro-wilk, kolmogorov-smirnov, lilliefors and anderson-darling tests. Journal of statistical modeling and analytics, 2(1), 21-33. [Google Scholar]

Rekunenko, I. I., Hrytsenko, L. L., Boiarko, I. M., \& Kostyrko, R. A. (2019). Financial debt market in the system of indicators of development of the economy of the country. Financial and credit activity: problems of theory and practice, 2(29), 430-439. [Google Scholar] [CrossRef]

Rose, A., \& Liao, S. Y. (2005). Modeling regional economic resilience to disasters: A computable general equilibrium analysis of water service disruptions. Journal of Regional Science, 45(1), 75-112. [Google Scholar] [CrossRef]

Shvindina, H. (2019). Coopetition as an emerging trend in research: perspectives for safety \& security. Safety, 5(3), 61. [Google Scholar] [CrossRef]

Simmie, J., \& Martin, R. (2010). The economic resilience of regions: towards an evolutionary approach. Cambridge journal of regions, economy and society, 3(1), 27-43. [Google Scholar] [CrossRef]

Supphellen, M., \& Nygaardsvik, I. (2002). Testing country brand slogans: Conceptual development and empirical illustration of a simple normative model. Journal of Brand Management, 9(4), 385-395. [Google Scholar] [CrossRef]

Supphellen, M., \& Nygaardsvik, I. (2002). Testing country brand slogans: Conceptual development and empirical illustration of a simple normative model. Journal of Brand Management, 9(4), 385-395. [Google Scholar] [CrossRef]

Van De Klundert, T. (1986). Economic resilience: a two-country analysis. De economist, 134(1), 25-41. [Google Scholar] [CrossRef

Vasylieva, T. A., Harust, Y. V., Vynnychenko, N. V., \& Vysochyna, A. V. (2018). Optimization of the financial decentralization level as an instrument for the country's innovative economic development regulation. [Google Scholar] [CrossRef]

Vasylieva, T. A., Lieonov, S. V., Petrushenko, Y. M., \& Vorontsova, A. S. (2017). Investments in the system of lifelong education as an effective factor of socio-economic development. Financial and credit activity: problems of theory and practice, 2(23), 426-436. [Google Scholar] [CrossRef] 
S. Shymon, E. Kolomiets-Ludwig, Jo. Osiejewicz, D. Krawczyk, B. Kaminska. The Role of Country Brand in Providing Economic Resilience

Світлана Шимон, д.ю.н., доцент, Київський національний економічний університет імені Вадима Гетьмана (Україна);

Євгенія Коломієць-Людвіг, к.ю.н., Київський національний економічний університет імені Вадима Гетьмана (Україна),

Йоанна Осієвіч, Варшавський університет (Польща);

Даріуш Кравчик, Ph.D., Департамент звязків міста Забже (Польща);

Божена Камінська, Ph.D., Лондонська академія наук та бізнесу (Великобританія).

Роль бренду країни в забезпеченні економічної безпеки

Ця стаття узагальнює аргументи та контраргументи в межах наукової дискусії з питання забезпечення економічної безпеки країни. Проведений в роботі бібліометричий аналіз публікацій за темою «економічна безпека» з використанням інструменту VOSviewer дозволив виділити чотири основні наукові школи. Систематизація літературних джерел та підходів до вирішення проблеми засвідчила, що основними компонентами оцінки рівня економічної безпеки країни $\epsilon$ : макроекономічна стабільність, мікроекономічна ефективність ринку, добре урядування, соціальний розвиток. Метою проведеного дослідження $\epsilon$ дослідження впливу маркетингової детермінанти на рівень економічної безпеки країни. Основною гіпотезою статті $є$ відсутність статистично значимої різниці в рівні економічної безпеки для країн які впроваджують ефективну політику просування свого бренду та які не здійснюють відповідних заходів. Методичним інструментарієм перевірки висунутої гіпотези стали: методи перевірки на нормальний розподіл ознак в статистичних сукупностях, з яких вилучені вибірки, за допомогою тесту Shapiro-Wilk; перевірки рівності дисперсій досліджуваних ознак в статистичних сукупностях з яких вилучені вибірки, за допомогою Levene's test; параметричний (One-way ANOVA: F-test) aбо не параметричний тест (Kruskal-Wallis rank test). Об'єктом дослідження обрані країни Європейського Союзу, які відповідно до рейтингу FutureBrand були поділені на 6 груп. В статті представлено результати емпіричного аналізу, який підтвердив висунуту в роботі гіпотезу. Дослідження емпірично підтверджує відсутність статистично значимої різниці між основними індикаторами рівня економічної безпеки країни відповідно до базової компоненти - макроекономічна стабільність, що оцінюеться за допомогою показників: дефбіцит або профіцит державного бюджету, рівень безробіття.

Ключові слова: бренд, дефіцит бюджету, профіцит бюджету, рівень безробіття, ANOVA.

Manuscript received: 25.12.2019.

(C) The author(s) 2020. This article is published with open access at Sumy State University. 